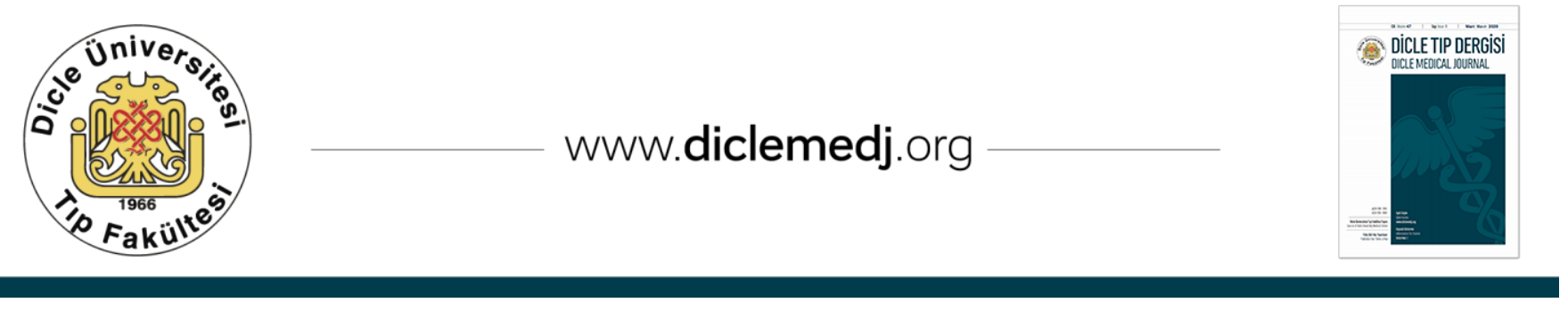

Original Article / Özgün Araştırma

\title{
The Effect of Metabolic PET Parameters on Survival Outcome in Malignant Pleural Mesothelioma
}

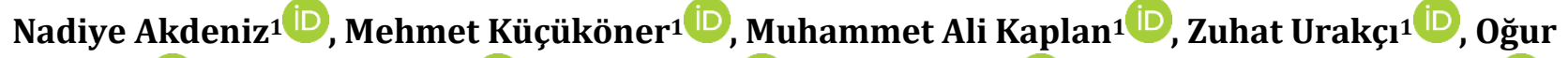

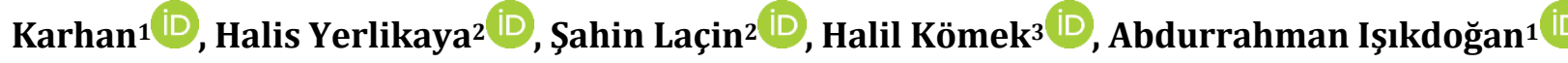 \\ 1 Department of Medical Oncology, Dicle University Medical Faculty, Diyarbakır, Turkey \\ 2 Department of Medical Oncology, Gazi Yasargil Education and Training Hospital, Diyarbakır, Turkey \\ 3 Department of Nuclear Medicine, Gazi Yasargil Education and Training Hospital, Diyarbakır, Turkey \\ Received: 14.07.2019; Revised: 12.12.2019; Accepted: 07.01.2020
}

\begin{abstract}
Objective: 18-Fluorodeoxyglucose positron emission tomography-computed tomography (18F-FDG PET-CT) is one of the most valuable imaging types and tumor metabolic volume is another parameter that can be obtained from PET-CT. Our primary objective is to evaluate the effect of PET-CT metabolic parameters on survival in patients with malignant pleural mesothelioma (MPM).
\end{abstract}

Methods: A total of 29 patients with MPM had been evaluated with 18F-FDG PET-CT between January 2016 and December 2017. Metabolic tumor volume (MTV), total lesion glycolysis (TLG), standardized uptake values (SUVmax) and TLG/liver SUVmean values were calculated. Also, effects of these parameters on survival rates were evaluated.

Results: Histological subtypes of the disease were determined as epithelioid $(n=24)$, biphasic $(n=3)$, sarcomatoid ( $n=2)$. Median overall survival was 255 days (21-903). Median MTV was $225 \mathrm{~cm}^{3}$ (10-1879), median TLG was $1056 \mathrm{~g} / \mathrm{ml}^{*} \mathrm{~cm}^{3}$ (36-18927), median SUVmax was 7.7 (1.5-20) and TLG/liver SUVmean ratio was 561.2 (14.9-8113.7). Sensitivity and specificity for MTV 113 cut-off value were $86.4 \%$ and $85.7 \%$, respectively. Determined cut-off value for TLG was 419.5 , sensitivity and specificity of the value were $81.8 \%$ and $85.7 \%$, respectively. Additionally, determined cut-off value for TLG/liver SUVmean ratio was 107.4, the rate of sensitivity and specificity for this value were $95.5 \%$ and $71.4 \%$, respectively. The patients with higher MTV, TLG and TLG/liver SUVmean had worse survival rate.

Conclusion: We confirmed significant association between MTV, TLG and TLG/liver SUVmean values and patients survival. These promising PET derived parameters can be used for evaluating treatment response and prognosis in MPM.

Keywords: Malignant pleural mesothelioma, survival, FDG PET/CT, metabolic tumor volume, total lesion glycolysis

DOI: 10.5798/dicletip.705798

Correspondence / Yazıșma Adresi: Nadiye Akdeniz, Department of Medical Oncology, Dicle University Medical Faculty, Diyarbakır, Turkey e-mail: nadiyeakdeniz21@gmail.com 


\section{Malign Plevral Mezotelyomada Metabolik PET Parametrelerinin Sağkalım Üzerine Etkisi}

\section{Öz}

Amaç: 18-Florodeoksiglukoz pozitron emisyon bilgisayarlı tomografi (18F-FDG PET-BT) en değerli görüntüleme yöntemlerinden biridir ve metabolik tümör volümü de PET-BT'den elde edilebilecek başka bir parametredir. Bu çalışmada MPM'de metabolik PET-BT parametrelerinin sağkalım üzerine etkisini değerlendirmeyi amaçladık.

Yöntemler: Çalışmaya Ocak 2016 - Aralık 2017 tarihleri arasında tedavi öncesi 18F-FDG PET-BT çekimi yaplan 29 hasta dahil edildi. Tüm hastaların metabolik tümör volümü (MTV), total lezyon glikolizi (TLG), standardize tutulum değerleri (SUVmax) ve total lezyon glikolizi/karaciğer SUVmean (TLG/KC SUVmean) değerleri hesaplandı. Ayrıca bu parametrelerin sağkalım üzerine etkileri değerlendirildi.

Bulgular: Histolojik alt tip olarak epitelioid $(n=24)$, bifazik $(n=3)$ ve sarkomatoid $(n=2)$ alt gruplardan oluşmaktaydı. Ortanca sağkalım 255 (21 - 903) gün idi. Median MTV değeri $225 \mathrm{~cm}^{3}$ (10-1675), median TLG değeri $1056 \mathrm{~g} / \mathrm{ml}^{*} \mathrm{~cm}^{3}$ (361776), median SUVmax değeri 7.7 (1.5-20) ve median TLG/KC SUVmean değeri 561,2 (14.9-8113.7) idi. MTV için cut off değer olarak 113 alındığında sensitivite \%86,4 ve spesifite \%85,7 idi. TLG için cut off değer olarak 419.5 alındığında sensitivite \%81,8 ve spesifite \%85,7 idi. Ayrıca TLG/KC SUVmean için cut off değer olarak 107.4 alındığında sensitivite \%95,5 ve spesifite \%71,4 idi. Yüksek MTV, TLG ve TLG/KC SUVmean'li hastalarda sağkalım oranları daha kötüydü.

Sonuç: Çalışmamızda MTV, TLG ve TLG/karaciğer SUVmean değerlerinin sağkalım ile anlamlı bir şekilde ilişkili olduğunu doğrulamış olduk. Bu PET BT parametreleri MPM'de tedavi yanıtını ve prognozu belirlemede kullanılabilir.

Anahtar kelimeler: Malign plevral mezotelyoma, sağkalım, FDG PET/BT, metabolik tümör volümü, total lezyon glikolizi.

\section{INTRODUCTION}

Exposure to asbestos dust is the most common reason of malignant pleural mesothelioma (MPM). After asbestos exposure, disease development is required for a long time, so the incidence continues to increase after exposure. MPM is a rapidly progressive disease and life expectancy for patients who cannot be operated is around 9-14 months ${ }^{1}$.

The EORTC (The European Cancer Research and Treatment Organization) and CALGB (Cancer and Leukemia Group B) have developed two prognostic scoring systems for patients with malignant mesothelioma ${ }^{2,3}$. However, clinicians do not prefer these scoring systems because they require high cost and time.

In MPM, radiological evaluation has very important place in diagnosis, also is crucial for predicting treatment response or response monitoring in treatment naive or relapsed patients ${ }^{4}$.
18-Fluorodeoxyglucose positron emission tomography-computed tomography (18F-FDG PET-CT) is one of the most valuable imaging types in the evaluation of MPM. Standardized uptake value like SUVmax values which obtained from initial 18F-FDG PET-CT before treatment in MPM have been reported as a prognostic factor that independent of histological subtype ${ }^{5}$. The response assessment of chemotherapy that used for MPM is very important in deciding whether to continue or change treatment. Tumor metabolic response that measured with 18F-FDG PET-CT is considered as a very useful way to assessment of efficacy of treatment. Tumor metabolic volume is another parameter that can be obtained from 18F-FDG PET-CT was used in the trial that done by Francis RJ et al ${ }^{6}$. They used volume-based parameters such as metabolic tumor volume (MTV) and total lesion glycolysis (TLG) for the first time and reported that these parameters volume-based predicted better overall survival and treatment response than 
SUVmax. The goal of our study was to assess the effect of volume-based metabolic 18F-FDG PETCT parameters on survival estimation in patients with MPM.

\section{METHODS}

A total of 29 patients with MPM who had been assesed with 18F-FDG PET-CT between January 2016 and December 2017 were included. The exclusion criteria of the study were lymph node metastatic patients or distant metastasis. MTV, TLG, SUVmax values and total lesion glycolysis/liver SUVmean (TLG/Liver SUVmean) values were calculated from all patients. The study designed in retrospective manner. The approval of our study was obtained from the Local Ethics Committee (permit no: 172/2018).

\section{F-FDG PET-CT}

The patients enrolled to the study were fasted and intravenous (IV) glucose infusion was prohibited for minimum 6 hours before the procedure. Blood glucose levels were confirmed to be equal or less than $140 \mathrm{mg} / \mathrm{dL}$ before $18 \mathrm{~F}$ FDG infusion. Approximately (444-555 MBq) $5.5 \mathrm{MBq} / \mathrm{kg}$ of FDG was applicated intravenously per patient, one hour before imaging.

The computed tomography was choiced with the Biograph 6 PET/CT (Siemens Medical Systems, CTI, Knoxville, TN, USA) device 60 minutes after the injection $(120 \mathrm{kV}, 110 \mathrm{~mA}$, $600 \mathrm{~mm}$ transaxial FOV, no gap, $10 \AA ̊ \sim 1.5 \mathrm{~mm}$ collimation, pitch 1.1. 0.5 s rotation time, $5 \mathrm{~mm}$ slice thickness, $512 \AA ̊ 212$ matrix) and (3D FOV $15.5 \mathrm{~cm}$, OSEM 2 iterations/8 subset, FWHM $5 \mathrm{~mm}$ ) PET images were acquired from the skull base to the upper legs, to be 3 mins per bed, with the patient in a supine position. Some patients were administered intravenously contrast before the computed tomography imaging. Attenuation-corrected emission data were obtained using the non-contrast enhanced or contrast enhanced computed tomography data extrapolated to $511 \mathrm{keV}$.

\section{Imaging and quantitative data analysis}

All 18F-FDG PET-CT images were analysed on PET-VCAR software (PET Volume Computerized Assisted Reporting, GE USA) (GE Advantage Workstation software version AW 4.7) by 2 nuclear medicine specialists who have at least 10 years experience in the field. The manual adjustment in three plan was done for target region to exclude adjacent physiologic FDG avid structures. In the volumetric target area, SUVmax was defined as maximum voxel density. The MTV was defined as a threshold of $50 \%$ of the maximum signal intensity. The sum of every individual lesion MTV is represented patient MTV. As the product of MTV and the SUVmean, the TLG was calculated 7 . Furthermore, as a composite parameter TLG was calculated which was determined by multiplying MTV by SUVmean TLG/liver SUVmean value was also obtained by dividing the TLG from the liver to the SUVmean value obtained from ROI.

\section{Statistical Analysis}

Study variables were analyzed with SPSS 21.0 statistics program. Quantitative variables were indicated as mean \pm Standard Deviation (SD) / Minimum - Maximum and median and categorical variables as $\mathrm{n}$ (\%). The Independent-Samples $\mathrm{T}$ test was used to compare parametric variables; Mann Whitney U test was used to compare nonparametric variables. Fisher Exact test was used to compare categorical variables. Optimum cut off (estimation), sensitivity and specificity values of MTV, TLG and TLG/liver SUVmean variables were examined and analyzed by ROC curve analysis. In order to investigate the effects of reestablished MTV, TLG and TLG/liver SUVmean factors on mortality and survival, according to the statistically significant predictive values obtained in the ROC curve, Kaplan-meier-Log 
Rank (Mantel-Cox) analysis were applied. The variables were examined at $95 \% \mathrm{Cl}$ (confidence level) and $\mathrm{p}$ value $<0.05$ was accepted as statistical significant.

\section{RESULTS}

Table I. Patient characteristics and metabolic PET parameters in alive and dead patients

\begin{tabular}{|c|c|c|c|c|c|}
\hline & & Alive & Exitus & Total & \multirow{2}{*}{$\mathbf{p}$} \\
\hline & & $(n=7)$ & $(n=22)$ & $(\mathrm{N}=29)$ & \\
\hline & & n (\%) & n (\%) & n (\%) & \\
\hline \multicolumn{6}{|l|}{ Gender } \\
\hline & Female & 5 (71.4) & $9(40.9)$ & $14(48.3)$ & $0.215^{\mathrm{a}}$ \\
\hline & Male & $2(28.6)$ & 13 (59.1) & 15 (51.7) & \\
\hline & & $\begin{array}{l}\text { Mean } \pm \text { SD. / } \\
\text { Min. - Max. }\end{array}$ & $\begin{array}{l}\text { Mean } \pm \text { SD. } \\
\text { Min. - Max. }\end{array}$ & $\begin{array}{l}\text { Mean } \pm \text { SD. } \\
\text { Min. - Max. }\end{array}$ & \\
\hline \multicolumn{2}{|l|}{ Age } & $\begin{array}{l}57.29 \pm 8.28 \\
48-72\end{array}$ & $\begin{array}{l}61.50 \pm 12.66 \\
36-91\end{array}$ & $\begin{array}{l}60.48 \pm 11.76 \\
36-91\end{array}$ & $0.308^{b}$ \\
\hline & & $\begin{array}{l}\text { Median } \\
\text { (Min. - Max.) }\end{array}$ & $\begin{array}{l}\text { Median (Min. - } \\
\text { Max.) }\end{array}$ & $\begin{array}{l}\text { Median (Min. - } \\
\text { Max.) }\end{array}$ & \\
\hline \multicolumn{2}{|c|}{ Overall survival } & $\begin{array}{lll}370 & (304 & - \\
570) & & \end{array}$ & $\begin{array}{lll}218.5 & (21 & - \\
903) & & \end{array}$ & $255(21-903)$ & $0.005^{c}$ \\
\hline \multicolumn{2}{|l|}{ MTV } & $47(10-217)$ & $\begin{array}{l}352.5(18 \\
1879)\end{array}$ & $\begin{array}{lll}225 & (10 & - \\
1879) & & \end{array}$ & $0.001^{c}$ \\
\hline \multicolumn{2}{|l|}{ TLG } & $\begin{array}{lll}238 & (36 & - \\
1320) & & \end{array}$ & $\begin{array}{l}1674(96- \\
18927)\end{array}$ & $\begin{array}{l}1056(36- \\
18927)\end{array}$ & $<0.001 \mathrm{c}$ \\
\hline \multicolumn{2}{|l|}{ Suvmax } & $6.3(3.4-20)$ & $8.8(1.5-18.1)$ & $7.7(1.5-20)$ & $0.512^{c}$ \\
\hline \multicolumn{2}{|c|}{$\begin{array}{l}\text { TLG/Liver } \\
\text { SUVmean }\end{array}$} & $\begin{array}{l}85.3(14.9- \\
586.7)\end{array}$ & $\begin{array}{l}\text { 771.95(66.3- } \\
8113.7)\end{array}$ & $\begin{array}{l}\text { 561.2(14.9- } \\
8113.7)\end{array}$ & $<0.001 \mathrm{c}$ \\
\hline
\end{tabular}

aFisher Exact test, $b$ Independent Sample T Test, c Mann Whitney $U$ test, SD:Standard Deviation, Min.:Minimum, Max.:Maximum, MTV:Metabolic tumor volume, TLG:Total lesion glycolysis, Standardized uptake values: SUVmax

Fifteen $(51.7 \%)$ of patients were male and $60.48 \pm 11.76$ years was the mean age of all patients. Histological subtypes of the disease in tumor tissues were determined as epithelioid $(n=24)$, biphasic $(n=3)$ and sarcomatoid $(n=2)$. Twenty-three of 29 patients with MPM had been treated with same chemotherapy regimen, which was consisted of platinum and pemetrexed combination. While 22 (75.9\%) deaths had occurred, 7 (24.1\%) patients were alive and on follow-up. Median overall survival was 255 days (21-903). Median MTV was 225 $\mathrm{cm}^{3}$ (10-1879), median TLG was 1056 $\mathrm{g} / \mathrm{ml}^{*} \mathrm{~cm}^{3}$ (36-18927), median SUVmax was 7.7 (1.5-20) and TLG/liver SUVmean ratio was 561.2 (14.9-8113.7) (Table 1). Sensitivity and specificity for MTV 113 cut-off value were $86.4 \%$ and $85.7 \%$, respectively.

Table II. Sensitivity and specificity values, according to cut-off values of volume based PET parameters

\begin{tabular}{|c|c|c|c|c|c|}
\hline \begin{tabular}{|l} 
Dependent \\
variables \\
(Mortality)
\end{tabular} & Cut-Off & $\begin{array}{l}\text { Sensitivit } \\
\mathbf{y}\end{array}$ & $\begin{array}{l}\text { Specificit } \\
\mathbf{y}\end{array}$ & AUC (SE.) & $\mathbf{p}$ \\
\hline MTV & Alive $<113<$ Ex & $86.4 \%$ & $85.7 \%$ & $\begin{array}{l}0.890 \\
(0.062)\end{array}$ & 0.002 \\
\hline TLG & $\begin{array}{l}\text { Alive }<419.5< \\
\text { Ex }\end{array}$ & $81.8 \%$ & $85.7 \%$ & $\begin{array}{l}0.864 \\
(0.071)\end{array}$ & 0.004 \\
\hline $\begin{array}{l}\text { TLG/LiverSUVme } \\
\text { an }\end{array}$ & $\begin{array}{l}\text { Alive }<107.4< \\
\text { Ex }\end{array}$ & $95.5 \%$ & $71.4 \%$ & $\begin{array}{l}0.896 \\
(0.066)\end{array}$ & 0.002 \\
\hline
\end{tabular}

ROC (Receiver Operating Curve) Analysis, AUC:Area under the ROC curve, SE: Standart Error, MTV:Metabolic tumor volume, TLG:Total lesion glycolysis, Standardized uptake values: SUVmax

Survival rate was worse in patients with high MTV, TLG and TLG/liver SUVmean $(\mathrm{p}=0.002$, $\mathrm{p}=0.004$ and $\mathrm{p}=0.002$, respectively) (Table 3 ) (Figure 1). 

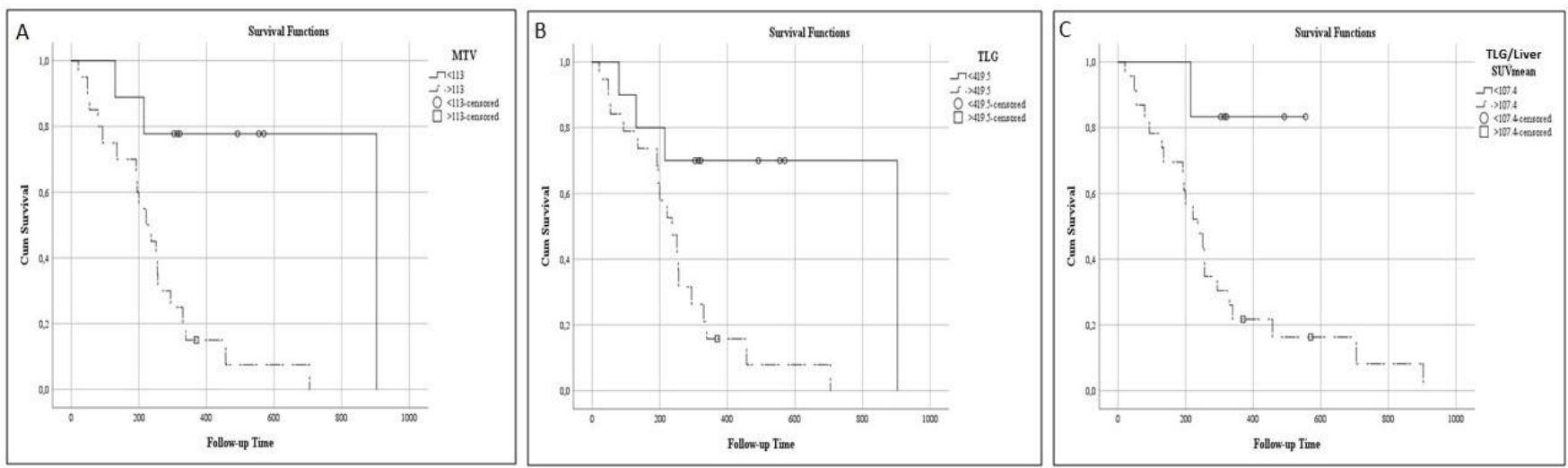

Figure 1. Kaplan-meier survival curves according to MTV (A), TLG (B), TLG/liver SUVmean (C)

Table III. First, second, and third year survival rates of the patients according to their volume-based PET parameters

\begin{tabular}{|c|c|c|c|c|c|}
\hline & Dead & Alive & $\begin{array}{l}\text { Estimate } \\
\text { Survival }\end{array}$ & \begin{tabular}{|l} 
Estimate \\
Proportion \\
Surviving at the
\end{tabular} & $\mathbf{p}$ \\
\hline & n(\%) & n(\%) & Mean \pm SE & $1 / 2$ / 3 Year & \\
\hline \multicolumn{6}{|l|}{ MTV } \\
\hline$<113$ & $3(33.3)$ & $6(66.7)$ & $740.7 \pm 124.25$ & 77.8 / 77.8 / 77.8 & \multirow{2}{*}{0.002} \\
\hline$>113$ & $19(95.0)$ & $1(5.0)$ & $247.2 \pm 40.54$ & $15 / 0 / 0$ & \\
\hline \multicolumn{6}{|l|}{ TLG } \\
\hline$<419.5$ & $4(40.0)$ & $6(60.0)$ & $674.5 \pm 127.94$ & $70 / 70 / 70$ & 0.008 \\
\hline$>419.5$ & $18(94.7)$ & $1(5.3)$ & $256.0 \pm 41.70$ & $15.8 / 0 / 0$ & \\
\hline \multicolumn{6}{|l|}{$\begin{array}{l}\text { TLG/Liver } \\
\text { SUVmean }\end{array}$} \\
\hline$<107.4$ & $1(16.7)$ & $5(83.3)$ & $498.3 \pm 51.73$ & 83.8 / 83.3 / 83.3 & 0.022 \\
\hline$>107.4$ & $21(91.3)$ & $2(8.7)$ & $300.7 \pm 54.23$ & $21.7 / 83.2 / 0$ & \\
\hline Total & $22(75.9)$ & $7(24.1)$ & $370.1 \pm 58.86$ & $32.2 / 13.4 / 0$ & \\
\hline
\end{tabular}

Kaplan Meier Test Log Rank (Mantel-Cox), SE:Standart Error, MTV:Metabolic tumor volume, TLG:Total lesion glycolysis, Standardized uptake values: SUVmax

According to multivariant analysis none of these parameters was independent prognostic factor. 18F-FDG PET-CT imaging and volume-based quantitative FDG PET-CT parameters of 64 years old women shown in figure 2 .

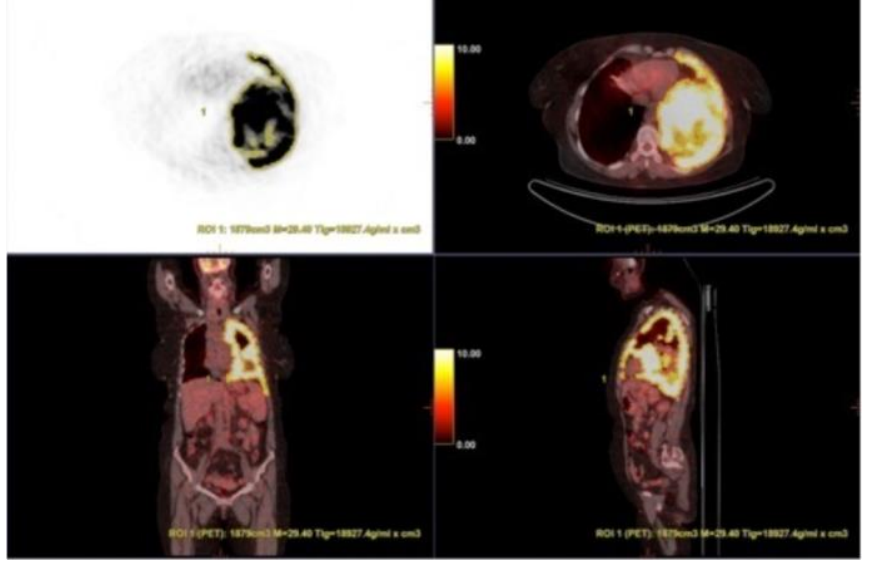

Figure 2. FDG PET/CT imaging in a 64-year-old female patient showing uptake in the left pleura. The PET-derived parameters were $\mathrm{MTV}=1879 \mathrm{~cm}^{3}, \mathrm{TLG}=18927.4 \mathrm{~g} / \mathrm{ml}^{*} \mathrm{~cm}^{3}$, SUVmax: 18 and OS was 294 days

\section{DISCUSSION}

The EORTC ${ }^{2}$ and the CALGB $^{3}$ have identified several prognostic factors which based on prospective trials that include pooled cohorts of chemotherapy treated patients; low performance status, non-epithelial histology, advanced disease stage, male sex, older age and low hemoglobin level were associated with worse prognosis. Modified Glasgow Prognostic Score is anothor parameter that can be used for detecting the severity of patients with MPM${ }^{8}$. Additionally, metabolic activity and tumor volume were determinative on prognosis as well ${ }^{9-12}$.

Initial studies based on FDG PET and PET-CT in patients with MPM were evaluated according to 
SUVmax values and results were controversial. In previous studies high SUVmax values were reported as poor prognostic factors and survival was short in MPM patients who had SUVmax value higher than 1013-15. Similarly, SUVmax was defined as an independent predictor factor of survival in other studies, which had compared and found statistically significant difference between 10.7 and 5 cut-off values ${ }^{5,16}$.

In contrast to these studies, Nowak et al. ${ }^{9}$ couldn't find any role of SUVmax to predict survival. As consistent with this study, we couldn't find any cut-off value of SUVmax for prediction to survival, also the relation between survival and SUVmax values was not significant.

The SUVmax value obtained from 18F-FDG PETCT and measuring based on single-pixel was used to predict the prognosis and treatment sensitivity of various tumors. The usage of SUVmax alone is limited due to heterogeneous tumor geometry and activity in MPM. MTV and TLG are three-dimensional measurements that including total tumor volume and metabolic activity. Therefore, these parameters are more sensitive to the SUVmax value obtained from a single pixel in the assessment of prognosis and treatment response ${ }^{17}$.

Lee HY et al. ${ }^{18}$ reported the results of a trial that included 13 patients with MPM, they calculated TLG, MTV, SUVmax, and SUVmean of the primary tumor and found MTV as significant different parameter between subgroups who with or without progression. In contrast to MTV parameter, both of SUVmax and SUVmean were not significant. MTV and TLG were reported as good predictive parameters for tumor progression and accepted as independent factors that associated with it.

In a recently reported study with univariate analysis; MTV and TLG have been reported to be associated with survival in treated MPM patients. In the trial, the poorer survival were determined in patients who had worse prognosis which indicated by these parameters that obtained from PET, therefore these results were promising to be further evaluated for stratifying patients in future trials ${ }^{19}$. In our study, we found TLG and MTV values as poor prognostic factors in the univariate analysis like reported in the previous study. Additionally, the cut-off values that we found for MTV and TLG were $113 \mathrm{~cm}^{3}$ and $419.5 \mathrm{~g} / \mathrm{ml}^{*} \mathrm{~cm}^{3}$, respectively and these values were reported in the previous study as $39.6-755 \mathrm{~cm}^{3}$ for MTV and 334-2914 $\mathrm{g} / \mathrm{ml}^{*} \mathrm{~cm}^{3}$ for TLG $17,18,20$.

The retrospective design and limited number of patients were limitations of our study. In addition, patient numbers of the biphasic and sarcomatoid subtypes were relatively small and statistical analysis could not be performed for exact comparisons. However, low incidence of the MPM disease makes such limitations inevitable.

In conclusion, with our study we confirmed that in contrast to SUVmax values MTV, TLG and TLG/liver SUVmean values that derived from PET were significantly associated with survival. Large-scale prospective trials are required to change the daily practice from using SUVmax based PET/CT to the volume-based PET/CT parameters for evaluating patients with MPM and predicting much better their prognosis and survival.

Ethics Committee Approval: The study designed in retrospective manner. The approval of our study was obtained from the Local Ethics Committee (permit no: 172/2018).

Declaration of Conflicting Interests: The authors declare that they have no conflict of interest.

Financial Disclosure: No financial support was received. 


\section{REFERENCES}

1. Chapman A, Mulrennan S, Ladd B, Muers MF. Population-based Epidemiology and prognosis of mesothelioma in Leeds, UK. Thorax 2008; 63: 435-9.

2. Curran D, Sahmoud T, Therasse P, et al. Prognostic factors in patients with pleural mesothelioma: the European Organization for Research and Treatment of Cancer experience. J Clin Oncol 1998; 16: 145-52.

3. Herndon JE, Green MR, Chahinian AP, Corson IM, Suzuki Y, Vogelzang NI. Factors predictive of survival among 337 patients with mesothelioma treated between 1984 and 1994 by the cancer and Leukemia Group B. Chest 1998; 113: 723-31.

4. Nowak AK, Armato SG, Ceresoli GL, et al. Imaging in pleural mesothelioma: a review of imaging research presented at the 9th International Meeting of the International Mesothelioma Interest Group. Lung Cancer 2010; 70: 1-6.

5. Abakay A, Komek H, Abakay O, et al. Relationship between 18 FDG PET-CT findings and survival of 177 patients with malignant pleural mesothelioma. Eur Rev Med Pharmacol Sci 2013; 17: 1233-41.

6. Francis RJ, Byrne MJ, van der Schaaf AA, et al. Early prediction of response to chemotherapy and survival in malignant pleural mesothelioma using a novel semiautomated 3-dimensional volume-based analysis of serial 18F-FDG PET scans. J Nucl Med 2007; 48: 1449-58.

7. Meignan M, Sasanelli M, Casasnovas R0, et al. Metabolic tumour volumes measured at staging in lymphoma: methodological evaluation on phantom experiments and patients. Eur J Nucl Med Mol Imaging 2014; 41: 1113-22.

8. Tanrıkulu Ç, Abakay Ö, Sezgi C, et al. Value of a new inflammatory parameter in malignant pleural mesotheliomaprognosis. Dicle Med J 2013; 40: 241-4.

9. Nowak AK, Francis RJ, Phillips MJ, et al. A novel prognostic model for malignant mesothelioma incorporating quantitative FDGPET imaging with clinical parameters. Clin Cancer Res 2010; 16: 2409-17.

10. Rusch VW, Venkatraman ES. Important prognostic factors in patients with malignant pleural mesothelioma, managed surgically. Ann Thorac Surg 1999; 68: 1799-804.

11. Pass HI, Temeck BK, Kranda K, Steinberg SM, Feuerstein IR. Preoperative tumor volume is associated with outcome in malignant pleural mesothelioma. J Thorac Cardiovasc Surg 1998; 115: 310-7.

12. Sugarbaker DJ, Strauss GM, Lynch TJ, et al. Node status has prognostic significance in the multimodality therapy of diffuse, malignant mesothelioma. J Clin Oncol 1993; 11: 1172-8.

13. Benard F, Sterman D, Smith RJ, Kaiser LR, Albelda SM, Alavi A. Prognostic value of FDG PET imaging in malignant pleural mesothelioma. J Nucl Med 1999; 40: 1241-5.

14. Flores RM. The role of PET in the surgical management of malignant pleural mesothelioma. Lung Cancer 2005; 49: 27-32.

15. Flores RM, Akhurst T, Gonen M, et al. Positron emission tomography predicts survival in malignant pleural mesothelioma. J Thorac Cardiovasc Surg 2006; 132: 763-8.

16. Gerbaudo VH, Mamede M, TrotmanDickenson B, Hatabu H, Sugarbaker DJ. FDG PET/CT patterns of treatment failure of malignant pleuralmesothelioma: relationship to histologic type, treatment algorithm, and survival. Eur J Nucl Med Mol Imag 2011; 38: 810-21.

17. Kitajima K, Doi $H$, Kuribayashi $K$, al. Prognostic value of pretreatment volume-based quantitative 18F-FDG PET/CT parameters in 
patients with malignant pleural mesothelioma. Eur J Radiol 2017; 86: 176-83.

18. Lee HY, Hyun SH, Lee KS, et al. Volumebased parameter of 18F-FDG PET/CT in malignant pleural mesothelioma: prediction of therapeutic response and prognostic implications. Annals Surg Oncol 2010; 17: 278794.

19. Incerti E, Broggi S, Fodor A, et al. FDG PETderived parameters as prognostic tool in progressive malignant pleural mesothelioma treated patients. Eur J Nucl Med Mol Imaging 2018; 45: 2071-8.
20. Zucali PA, Lopci E, Ceresoli GL, et al. Prognostic and predictive role of [18F] fluorodeoxyglucose positron emission tomography (FDG-PET) in patients with unresectable malignant pleural mesothelioma (MPM) treated with up-front pemetrexed-based chemotherapy. Cancer Med 2017; 6: 2287-96. 